\title{
INTEGRASI VIDEO CONFERENCE DALAM APLIKASI PEMBELAJARAN SISWA SEKOLAH DASAR UNTUK KEMUDAHAN INTERAKSI DAN EVALUASI PROSES BELAJAR MENGAJAR SECARA DARING
}

\author{
Agus Hermanto, Mochamad Sidqon \\ Program Studi Teknik Informatika, Fakultas Teknik, Universitas 17 Agustus 1945 Surabaya \\ Jl. Semolowaru No.45 \\ hermanto ifeuntag-sby.ac.id, sidqonuntag@gmail.com
}

\begin{abstract}
The rapid development of information technology is one of the most valuable potentials in efforts to improve the quality of education. With information technology, there is a lot of unlimited information that can be extracted for the benefit of the development of the world of education. SDN Karangsentul, which is the object of community service in this study, also does not escape and must be able to adapt to technological developments during teaching and learning activities. One form of implementing the use of technology in the world of education is an online teaching and learning system. In online learning, it is necessary to pay attention to the ease of interaction and evaluation in these learning activities. One of the efforts to improve the ease of interaction and evaluation of learning is by integrating online learning with the video conference feature. Based on these considerations to facilitate the interaction and evaluation of the online learning process, this community service activity will carry out the Integration of Video Conferences in Primary School Student Learning Applications for Ease of Interaction and Evaluation of the Online Teaching and Learning Process, so that online learning support can have a maximum impact on education development. In its construction, the SDLC method is used. And used whitebox testing methods and blackbox testing. The test results show that the system built works well and is able to answer existing problems.
\end{abstract}

Keywords - Online, Education, Community Service, Information Technology, Video Conference.

\begin{abstract}
Abstrak - Teknologi informasi yang berkembang semakin pesat merupakan salah satu potensi berharga dalam upaya peningkatan kualitas pendidikan. Dengan teknologi informasi banyak sekali informasi yang tak terbatas yang dapat digali demi kepentingan perkembangan dunia Pendidikan. Salah satu bentuk implementasi pemanfaatan teknologi dalam dunia Pendidikan adalah sistem belajar mengajar daring. Dalam pembelajaran daring, perlu diperhatikan kemudahan interaksi dan evaluasi dalam kegiatan pembelajaran tersebut. Salah satu upaya untuk meningkatkan kemudahan interaksi dan evaluasi pembelajaran adalah dengan mengintegrasikan pembelajaran daring dengan fitur video conference. Berdasarkan pertimbangan tersebut dalam rangka mempermudah interaksi dan evaluasi proses pembelajaran daring, pada kegiatan pengabdian masyarakat ini akan dilaksanakan Integrasi Video Conferece Dalam Aplikasi Pembelajaran Siswa Sekolah Dasar Untuk Kemudahan Interaksi dan Evaluasi Proses Belajar Mengajar Secara Daring, sehingga dukungan pembelajaran daring dapat berdampak maksimal pada perkembangan Pendidikan. Pada pembangunannya digunakan metode SDLC. Serta digunakan metode pengujian whitebox dan blackbox testing. Hasil pengujian menunjukkan sistem yang dibangun berhasil dengan baik dan mampu menjawab permasalahan yang ada.
\end{abstract}

Kata Kunci - Daring, Pendidikan, Pengabdian Masyarakat, Teknologi Informasi, Video Conference.

\section{PENDAHULUAN}

Pesatnya perkembangan teknologi ke arah yang serba digital di masa saat ini semakin meningkat. Pada era digital, masyarakat memiliki gaya hidup baru yang semakin bergantung dan tidak bisa dipisahkan dari perangkat elektronik. Teknologi Informasi telah menjadi alat yang dapat membantu mempermudah tugas, pekerjaan, serta kebutuhan masyarakat. Peran penting dari teknologi ini yang membawa peradaban masyarakat memasuki era digital saat ini [1].

Teknologi informasi pada saat ini sudah menjadi hal penting dalam upaya mendorong pertumbuhan organisasi. Kebutuhan terhadap penggunaan teknologi informasi yang telah menyebar di seluruh lini organisasi menyebabkan timbulnya kebutuhan akan tata kelola teknologi informasi.

Perkembangan teknologi informasi yang semakin pesat merupakan salah satu potensi berharga dalam upaya peningkatan kualitas pendidikan. Dengan teknologi informasi banyak sekali informasi tak terhingga yang mampu digali demi kepentingan perkembangan dunia Pendidikan. Pembelajaran tidak lagi terbatas oleh ruang serta waktu dengan adanya teknologi informasi [2].

Teknologi informasi bagi dunia Pendidikan juga membantu tersedianya saluran dan sarana untuk menyebarkan pembelajaran sehingga dapat tersebar 
secara luas. Dengan hadirnya keberadaan teknologi informasi mempermudah terlaksananya Pendidikan secara jarak jauh, sehingga penyebaran dan pemerataan Pendidikan dapat terlaksana dengan baik. Dalam bidang Pendidikan, teknologi informasi memegang peran penting terutama sebagai alat bantu dalam pemerataan dan penyebaran Pendidikan, sehingga dengan demikian kualitas Pendidikan dapat mengalami peningkatan [2].

Tujuan Pendidikan tidak hanya semata - mata untuk membangun kecerdasan intelektual saja, melainkan Pendidikan juga berperan dalam pembentukan watak, dan karakter yang baik. Oleh karena itu, Pendidikan memang sepatutnya mendapat perhatian baik bagi masyarakat [3].

Pendidikan juga dapat diartikan sebagai upaya sadar dalam rangka menciptakan generasi yang dapat menggali serta mengembangkan potensi diri, pengetahuan, teknologi, akhlak, dan akal budi dengan sangat baik [4].

Pembangunan Pendidikan juga merupakan upaya dalam mewujudkan tujuan nasional. Hal ini ditunjukkan sebagaimana yang tercantum dalam pembukaan UUD 1945 pada Alinea ke - 4 yang berbunyi "Memajukan kesejahteraan umum, mencerdaskan kehidupan bangsa, dan ikut serta melaksanakan ketertiban dunia". Tiap - tiap warga negara Indonesia berhak untuk mendapatkan Pendidikan yang dilangsungkan melalui sistem pendidikan nasional [5].

Dengan demikian, tentunya saat ini teknologi informasi sangat dibutuhkan dalam menunjang perkembangan Pendidikan. Saat ini, teknologi informasi memegang peran yang penting dalam dunia Pendidikan. Dengan memanfaatkan teknologi informasi dalam dunia Pendidikan diharapkan dapat mempermudah aktivitas belajar mengajar, diharapkan peserta didik dan pendidik dapat aktif memanfaatkan teknologi informasi dalam pencarian informasi sesuai dengan ilmu pengetahuan yang dibutuhkan dalam proses pembelajaran [6].

Dengan pesatnya arus perkembangan teknologi informasi akan menuntut masyarakat untuk beradaptasi ditengah arus perkembangan teknologi tersebut, tidak terkecuali pada bidang Pendidikan. Jika dalam perkembangan dunia Pendidikan tidak dapat menyesuaikan dengan perkembangan teknologi informasi, maka akan menyebabkan ketinggalan dan tidak dapat menyesuaikan dengan tantangan global. Dengan demikian perkembangan dunia Pendidikan tidak akan terlepas dari kemajuan teknologi informasi [6].

Peran teknologi informasi dalam perkembangan dunia Pendidikan mulai dirasakan dampak positifnya. Salah satunya, dengan kehadiran teknologi informasi ditengah perkembangan Pendidikan membuat jarak dan waktu bukan lagi menjadi masalah dalam aktivitas pembelajaran. Dengan perkembangan teknologi informasi, kegiatan belajar mengajar dapat dilaksanakan dengan lebih efisien, efektif, dan menarik [6].

Salah satu bentuk implementasi dari pemanfaatan teknologi informasi dalam dunia Pendidikan yang popular belakangan ini adalah sistem belajar mengajar dengan metode daring.

Pembelajaran daring dapat diartikan sebagai bentuk pembelajaran yang menggunakan jaringan internet dengan aksesibilitas, konektivitas, fleksibilitas, serta kemampuan dalam memunculkan berbagai macam interaksi pembelajaran. Pembelajaran dengan metode daring mampu memfasilitasi peserta didik dan pendidik untuk melaksanakan kegiatan belajar mengajar dengan bantuan internet. Proses belajar mengajar dengan metode daring membutuhkan dukungan perangkat seperti smarphone, laptop, komputer, maupun tablet yang dapat dipergunakan untuk mengakses informasi kapan saja dan dimana saja. Beberapa tahun terakhir, pembelajaran dengan metode daring telah menjadi tuntutan baru dalam dunia Pendidikan [7].

Teknologi untuk pembelajaran daring pada umumnya dibangun dalam platform website. Aplikasi website secara umum wajib mempunyai keandalan yang tinggi dalam arti bahwa server diharapkan mampu tersedia setiap waktu, mempunyai potensi untuk menarik serta menjangkau audiens secara luas, memiliki kegunaan dan visibilitas yang tinggi [8].

Dalam pembelajaran dengan metode daring, perlu diperhatikan juga kemudahan interaksi dan evaluasi dalam kegiatan pembelajaran tersebut. Salah satu upaya untuk meningkatkan kemudahan interaksi dan evaluasi pembelajaran adalah dengan mengintegrasikan pembelajaran daring dengan fitur video conference, sehingga pendidik dan peserta didik dapat lebih aktif dalam kegiatan belajar mengajar.

Beberapa penelitian terdahulu menunjukkan bahwa berbagai bentuk teknologi pembelajaran jarak jauh interaktif dapat menyebabkan perubahan positif dalam kegiatan pembelajaran jika dibandingkan dengan sistem pembelajaran jarak jauh yang dilangsungkan sebelumnya [9].

Berdasarkan pertimbangan tersebut dalam rangka mempermudah interaksi dan evaluasi proses pembelajaran dengan metode daring, pada kegiatan pengabdian masyarakat ini akan dilaksanakan Integrasi Video Conferece Dalam Aplikasi Pembelajaran Siswa Sekolah Dasar Untuk Kemudahan Interaksi dan Evaluasi Proses Belajar Mengajar Secara Daring, sehingga dukungan pembelajaran dengan metode daring dapat berdampak maksimal pada perkembangan Pendidikan.

\section{METODE PENELITIAN}

Tahapan kegiatan penelitian yang dilakukan dalam penelitian ini adalah sebagai berikut : 1) Studi Pustaka, untuk menemukan dan mempelajari teori- 
teori pendukung penelitian yang berkaitan dengan teknologi informasi, kemjuan pendidikan, metode pembelajaran daring, pembangunan sistem e-learning, integrasi video conference 2) Data Penelitian, Data yang diperoleh dari studi literatur serta data observasi dari objek penelitian. 3) Desain Sistem Aplikasi pembelajaran siswa Sekolah Dasar (SD) 4) Membangun Sistem Aplikasi pembelajaran siswa Sekolah Dasar (SD). 5) Pengujian Sistem, Pengujian sistem Aplikasi pembelajaran siswa Sekolah Dasar (SD) dalam hal validitas, keamanan, dan fungsionalitas. 6) Dokumentasi, dokumentasi hasil implementasi sistem Aplikasi pembelajaran siswa Sekolah Dasar (SD) yang telah dibuat dan diuji.

Tabel 1. Tahapan Kegiatan

\begin{tabular}{|c|c|c|c|}
\hline No & $\begin{array}{l}\text { Tahapan } \\
\text { Kegiatan }\end{array}$ & $\begin{array}{c}\text { Rincian } \\
\text { Kegiatan }\end{array}$ & Indikator Hasil \\
\hline 1 & $\begin{array}{c}\text { Tahap } \\
\text { Analisis }\end{array}$ & $\begin{array}{l}\text { Studi litelatur } \\
\text { dan studi data } \\
\text { penelitian }\end{array}$ & $\begin{array}{l}\text { Data dan teori } \\
\text { pendukung }\end{array}$ \\
\hline 2 & $\begin{array}{c}\text { Tahap } \\
\text { Perancangan }\end{array}$ & $\begin{array}{c}\text { Perancangan } \\
\text { aplikasi } \\
\text { pembelajaran } \\
\text { siswa Sekolah } \\
\text { Dasar (SD) } \\
\text { dengan integrasi } \\
\text { video } \\
\text { conference } \\
\end{array}$ & $\begin{array}{c}\text { Rancangan } \\
\text { aplikasi } \\
\text { pembelajaran } \\
\text { siswa Sekolah } \\
\text { Dasar (SD) } \\
\text { dengan } \\
\text { integrasi video } \\
\text { conference } \\
\end{array}$ \\
\hline 3 & $\begin{array}{c}\text { Tahap } \\
\text { Implementasi }\end{array}$ & $\begin{array}{c}\text { Membangun } \\
\text { aplikasi } \\
\text { pembelajaran } \\
\text { siswa Sekolah } \\
\text { Dasar (SD) } \\
\text { dengan integrasi } \\
\text { video } \\
\text { conference } \\
\end{array}$ & $\begin{array}{c}\text { Aplikasi } \\
\text { pembelajaran } \\
\text { siswa Sekolah } \\
\text { Dasar (SD) } \\
\text { dengan } \\
\text { integrasi video } \\
\text { conference }\end{array}$ \\
\hline 4 & $\begin{array}{c}\text { Tahap } \\
\text { Pengujian }\end{array}$ & $\begin{array}{c}\text { Pengujian } \\
\text { sistem }\end{array}$ & $\begin{array}{c}\text { Hasil uji } \\
\text { aplikasi } \\
\text { pembelajaran } \\
\text { siswa Sekolah } \\
\text { Dasar (SD) } \\
\text { dengan } \\
\text { integrasi video } \\
\text { conference }\end{array}$ \\
\hline 5 & Tahap Akhir & Dokumentasi & $\begin{array}{c}\text { Hasil } \\
\text { dokumentasi } \\
\text { sistem }\end{array}$ \\
\hline
\end{tabular}

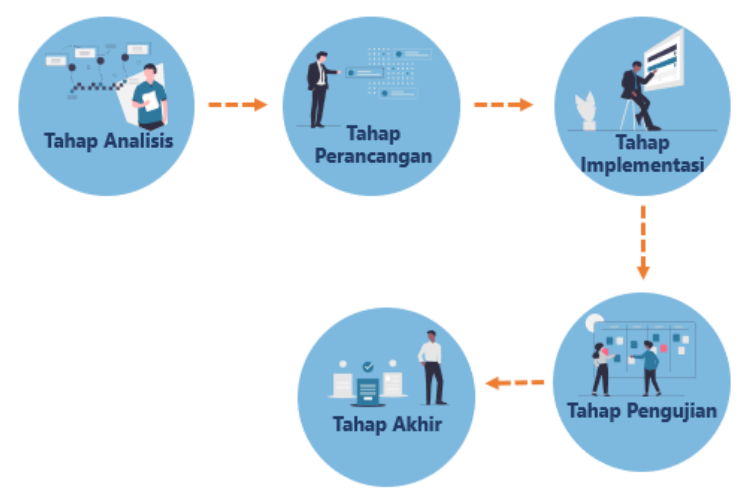

Gambar 1. Tahapan Kegiatan

\section{HASIL DAN PEMBAHASAN}

Berdasarkan pengamatan terhadap studi literature serta observasi terhadap objek penelitian dalam penelitian ini, menghasilkan analisis kebutuhan dalam bentuk fitur sistem pembelajaran siswa sekolah dasar : fitur deskripsi kelas, pengumuman, materi, ujian, tugas, dan diskusi.

Guru dapat membuat kelas baru melalui sistem pembelajaran untuk setiap kelas yang diampu. Kemudian, akan muncul kode kelas yang dapat dibagikan kepada peserta didik sehingga peserta didik dapat bergabung ke dalam kelas yang dibuat guru.

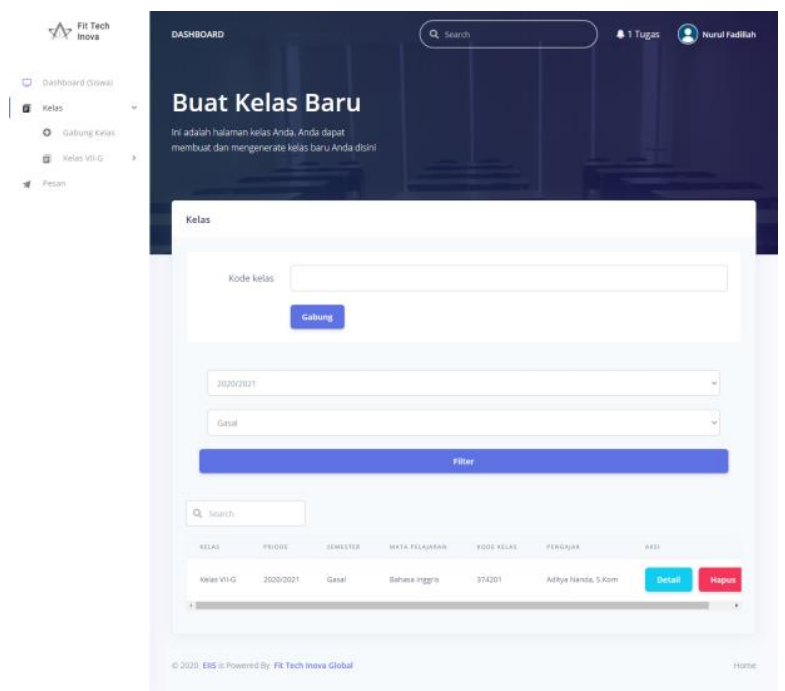

Gambar 2. Menu Buat Kelas Baru

Terdapat berbagai menu yang bisa diakses oleh guru serta peserta didik untuk melaksanakan proses belajar mengajar daring. Menu yang disediakan terdiri dari menu deskripsi kelas, menu pengumuman, menu materi, menu ujian, menu tugas, dan menu diskusi. Pada menu deskripsi kelas memungkinkan guru untuk memanajemen deskripsi masing - masing kelasnya. Pada menu pengumuman memungkinkan guru untuk mempublikasikan pengumuman kepada peserta didik, serta memungkinkan interaksi antara guru dan peserta didik melalui postingan pengumuman tersebut. Pada menu materi memungkinkan guru untuk dapat membagikan materi kepada peserta didik. Pada menu ujian dan tugas memungkinkan guru untuk menugaskan tugas dan ujian pada peserta didik dengan indikator waktu tertentu. Pada menu diskusi memungkinkan guru dan peserta didik melakukan interaksi melalui pesan maupun video conference. 


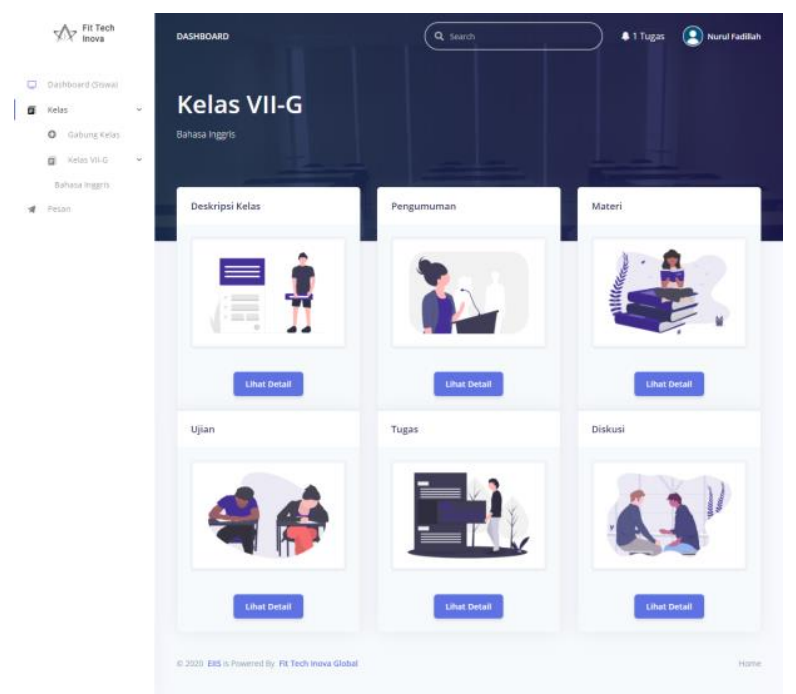

Gambar 3. Daftar Menu

Pada menu diskusi kelas sudah diintegrasikan dengan video conference agar pembelajaran lebih interaktif dan memudahkan interaksi dan evaluasi pada proses pembelajaran.

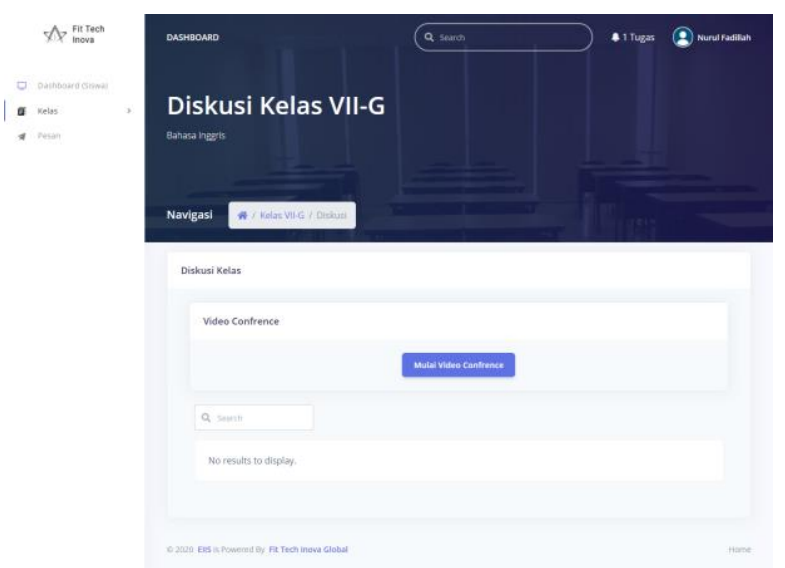

Gambar 4. Menu Diskusi

Video Conference dapat diakses dengan menekan tombol buat video conference yang tersedia pada menu diskusi kelas. Dengan demikian proses pembeajaran dapat dilaksanakan secara tatap muka melalui video conference. Video conference yang sudah tersedia di dalam sistem pembelajaran menjadikan kegiatan lebih efisien dan praktis tanpa perlu mengakses sistem lain dari luar sistem.
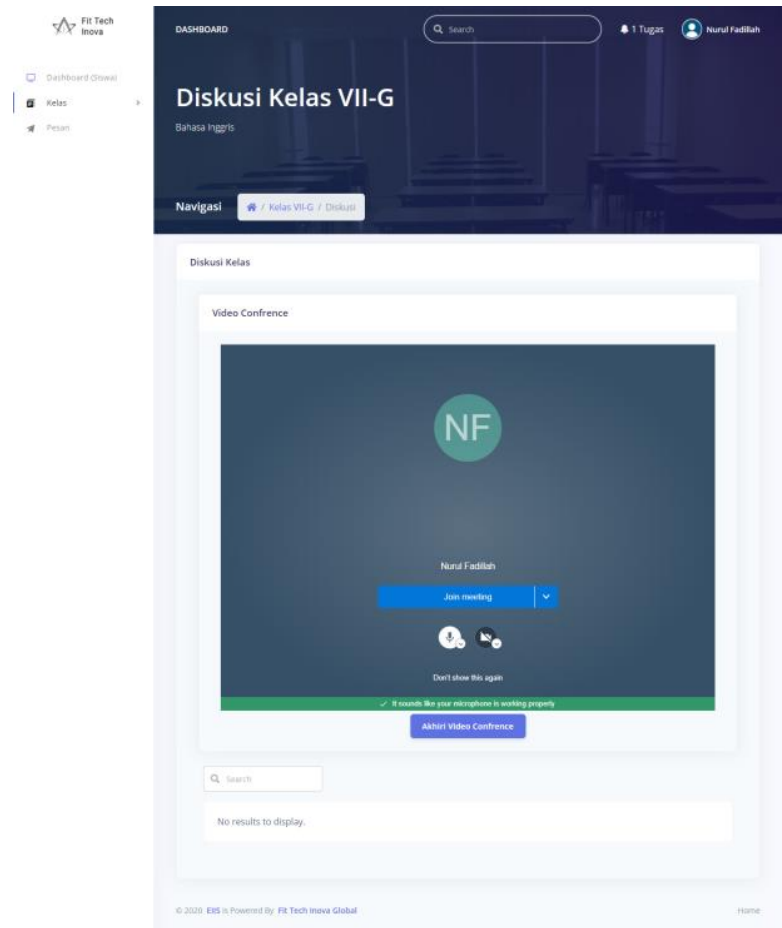

Gambar 5. Video Conference

Tampilan Sistem Informasi Keuangan yang dibangun juga sudah responsive dan mendukung tampilan mobile. Sehingga dapat memudahkan pengguna dalam mengakses sistem pembelajaran siswa Sekolah Dasar (SD) ini.

Pengujian yang digunakan dalam penelitian ini meliputi pengujian pada aspek kualitas untuk memastikan bahwa sistem berjalan di bawah persyaratan sistem, dan pengujian pada aspek keamanan untuk memastikan sistem yang dibangun sudah bisa dijamin keamanannya.

Pengujian pada sisi kualitas dilakukan dengan menguji fungsionalitas dan menguji kegunaan. Dalam pengujian fungsionalitas, digunakan metode pengujian blackbox. Pengujian blackbox difokuskan pada pengujian fungsional, portabilitas, dan reliabilitas. Pengujian Usabilitas sistem pembelajaran siswa Sekolah Dasar (SD) ini menggunakan kombinasi antara metode ServQual serta metode WebQual, yang digunakan untuk mengukur kualitas layanan dikombinasikan dengan dimensi usability [10]. Responden dalam pengujian ini adalah enduser dari sistem pembelajaran siswa Sekolah Dasar (SD).

Tabel 2. Pengujian Blackbox

\begin{tabular}{|c|c|c|c|c|}
\hline $\begin{array}{c}\text { Kelas } \\
\text { Uji }\end{array}$ & $\begin{array}{c}\text { Butir } \\
\text { Uji }\end{array}$ & $\begin{array}{l}\text { Skenario } \\
\text { Pengujian }\end{array}$ & Hasil Pengujian & $\begin{array}{l}\text { Kesim } \\
\text { pulan }\end{array}$ \\
\hline Login & $\begin{array}{l}\text { Verifik } \\
\text { asi } \\
\text { Userna } \\
\text { me dan } \\
\text { Passwo } \\
\text { rd }\end{array}$ & $\begin{array}{l}\text { Username } \\
\text { dan Password } \\
\text { tidak diisi } \\
\text { kemudian } \\
\text { klik tombol } \\
\text { Login }\end{array}$ & $\begin{array}{l}\text { Tidak berhasil } \\
\text { login, hanya } \\
\text { muncul toast } \\
\text { pada kotak form } \\
\text { email harus diisi } \\
\text { terlebih dahulu }\end{array}$ & valid \\
\hline & & $\begin{array}{l}\text { Mengisikan } \\
\text { Username, } \\
\text { tetapi }\end{array}$ & $\begin{array}{lr}\text { Tidak } & \text { berhasil } \\
\text { login, } & \text { hanya } \\
\text { muncul } & \text { toast }\end{array}$ & valid \\
\hline
\end{tabular}




\begin{tabular}{|c|c|c|c|c|}
\hline $\begin{array}{c}\text { Kelas } \\
\text { Uji }\end{array}$ & $\begin{array}{c}\text { Butir } \\
\text { Uji }\end{array}$ & $\begin{array}{c}\text { Skenario } \\
\text { Pengujian }\end{array}$ & Hasil Pengujian & $\begin{array}{l}\text { Kesim } \\
\text { pulan }\end{array}$ \\
\hline & & $\begin{array}{l}\text { password } \\
\text { tidak diisi } \\
\text { atau kosong } \\
\text { kemudian } \\
\text { klik tombol } \\
\text { Login }\end{array}$ & $\begin{array}{ll}\text { pada kotak form } \\
\text { password harus } \\
\text { diisi terlebih } \\
\text { dahulu }\end{array}$ & \\
\hline & & $\begin{array}{l}\text { Password dan } \\
\text { Username } \\
\text { tidak diisi } \\
\text { atau kosong } \\
\text { kemudian } \\
\text { klik tombol } \\
\text { Login }\end{array}$ & $\begin{array}{l}\text { Tidak berhasil } \\
\text { login, hanya } \\
\text { muncul toast } \\
\text { pada kotak form } \\
\text { email harus diisi } \\
\text { terlebih dahulu }\end{array}$ & valid \\
\hline & & $\begin{array}{l}\text { Mengisikan } \\
\text { Username } \\
\text { dan/atau } \\
\text { password } \\
\text { tidak sesuai, } \\
\text { kemudian } \\
\text { klik tombol } \\
\text { Login }\end{array}$ & $\begin{array}{l}\text { Tidak berhasil } \\
\text { login, muncul } \\
\text { pemberitahuan } \\
\text { bahwa } \\
\text { "kredensial ini } \\
\text { tidak cocok } \\
\text { dengan catatan } \\
\text { kami" dengan } \\
\text { font berwarna } \\
\text { merah } \\
\end{array}$ & valid \\
\hline & & $\begin{array}{l}\text { Mengisikan } \\
\text { Username } \\
\text { dan password } \\
\text { dengan benar, } \\
\text { kemudian } \\
\text { klik tombol } \\
\text { Login }\end{array}$ & $\begin{array}{l}\text { Berhasil login } \\
\text { dan diarahkan } \\
\text { ke halaman } \\
\text { Dashboard(Sisw } \\
\text { a). }\end{array}$ & valid \\
\hline $\begin{array}{c}\text { Profilk } \\
\text { u }\end{array}$ & $\begin{array}{l}\text { Ubah } \\
\text { Inform } \\
\text { asi } \\
\text { Profil } \\
\text { Akun }\end{array}$ & $\begin{array}{l}\text { Ubah nomor } \\
\text { hp yang ada } \\
\text { pada menu } \\
\text { Profilku } \\
\text { dengan } \\
\text { nomor } \\
\text { whatsapp } \\
\text { anda masing - } \\
\text { masing }\end{array}$ & \begin{tabular}{lr}
\multicolumn{2}{l}{ Nomor } \\
Whatsapp pada \\
profil berhasil \\
diubah & ditandai \\
dengan & kotak \\
form & No Hp \\
(WA) & berisi \\
nomor & yang \\
baru & di \\
daftarkan dan \\
muncul succes \\
allert berwarna \\
hijau rang \\
berisi bahwa \\
profil berhasil \\
di update.
\end{tabular} & valid \\
\hline & $\begin{array}{l}\text { Ubah } \\
\text { Passwo } \\
\text { rd }\end{array}$ & $\begin{array}{l}\text { Ubah } \\
\text { password } \\
\text { akun }\end{array}$ & $\begin{array}{l}\text { Password } \\
\text { berhasil diubah } \\
\text { ditandai dengan } \\
\text { muncul succes } \\
\text { allert berwarna } \\
\text { hijau yang } \\
\text { berisi bahwa } \\
\text { password } \\
\text { berhasil di } \\
\text { update. } \\
\text { (password baru } \\
=123456 \text { ). }\end{array}$ & valid \\
\hline Kelas & $\begin{array}{l}\text { Gabun } \\
\text { g Kelas } \\
\text { (Kode } \\
\text { Kelas : } \\
\mathbf{7 8 7 3 0 6} \\
\text { ) }\end{array}$ & $\begin{array}{l}\text { Isikan kode } \\
\text { kelas yang } \\
\text { tidak sesuai, } \\
\text { kemudian } \\
\text { klik tombol } \\
\text { gabung }\end{array}$ & $\begin{array}{l}\text { Tidak berhasil } \\
\text { bergabung ke } \\
\text { kelas, muncul } \\
\text { danger allert } \\
\text { berwarna merah } \\
\text { yang } \\
\text { menjelaskan } \\
\text { gagal } \\
\text { ditambahkan, } \\
\text { kode kelas } \\
\text { tidak valid. ( } \\
\text { kode yang di } \\
\text { inputkan = } \\
1222211111) \text {. }\end{array}$ & valid \\
\hline
\end{tabular}

\begin{tabular}{|c|c|c|c|c|}
\hline $\begin{array}{c}\text { Kelas } \\
\text { Uji }\end{array}$ & $\begin{array}{c}\text { Butir } \\
\text { Uji }\end{array}$ & $\begin{array}{l}\text { Skenario } \\
\text { Pengujian }\end{array}$ & Hasil Pengujian & $\begin{array}{c}\text { Kesim } \\
\text { pulan }\end{array}$ \\
\hline & & $\begin{array}{l}\text { Isikan kode } \\
\text { kelas yang } \\
\text { sesuai, } \\
\text { kemudian } \\
\text { klik tombol } \\
\text { gabung }\end{array}$ & $\begin{array}{l}\text { Berhasil } \\
\text { bergabung ke } \\
\text { kelas, muncul } \\
\text { succes allert } \\
\text { berwarna hijau } \\
\text { yang } \\
\text { menjelaskan } \\
\text { berhasil } \\
\text { ditambahkan } \\
\text { dan muncul } \\
\text { kelas yang } \\
\text { telah di } \\
\text { tambahkan pada } \\
\text { tabel kelas yang } \\
\text { berada pada } \\
\text { bagian bawah } \\
\text { dari filter. }\end{array}$ & valid \\
\hline & $\begin{array}{l}\text { Tampil } \\
\text { kan } \\
\text { Detail } \\
\text { Kelas }\end{array}$ & $\begin{array}{lr}\text { Pilih } & \text { detail } \\
\text { kelas } & \text { pada } \\
\text { daftar } & \text { kelas } \\
\text { yang } & \text { anda } \\
\text { ikuti } & \\
\end{array}$ & $\begin{array}{l}\text { Dialihkan ke } \\
\text { halaman detail } \\
\text { dari kelas yang } \\
\text { dipilih, dan } \\
\text { terdapat } \\
\text { beberapa menu : } \\
\text { Deskripsi Kelas, } \\
\text { Pengumuman, } \\
\text { Materi, Ujian, } \\
\text { Tugas, dan } \\
\text { Diskusi. }\end{array}$ & valid \\
\hline $\begin{array}{c}\text { Deskri } \\
\text { psi } \\
\text { Kelas }\end{array}$ & $\begin{array}{l}\text { Tampil } \\
\text { kan } \\
\text { Deskri } \\
\text { psi } \\
\text { Kelas }\end{array}$ & $\begin{array}{l}\text { Pilih menu } \\
\text { deskripsi } \\
\text { kelas pada } \\
\text { kelas yang } \\
\text { anda ikuti }\end{array}$ & $\begin{array}{lr}\text { Dialihkan } & \text { ke } \\
\text { halaman } & \\
\text { deskripsi } & \text { kelas } \\
\text { yang dipilih, } \\
\text { terdapat } & \text { tabel } \\
\text { deskripsi } & \text { kelas } \\
\text { dan tabel data } \\
\text { siswa } & \text { yang } \\
\text { terdaftar } & \text { pada } \\
\text { kelas } & \text { yang } \\
\text { dipilih. } & \\
\end{array}$ & valid \\
\hline \multirow[t]{2}{*}{$\begin{array}{l}\text { Pengu } \\
\text { muman }\end{array}$} & $\begin{array}{l}\text { Tampil } \\
\text { kan } \\
\text { Pengu } \\
\text { muman }\end{array}$ & $\begin{array}{lr}\text { Pilih } & \text { menu } \\
\text { pengumuman } \\
\text { pada } & \text { kelas } \\
\text { yang } & \text { anda } \\
\text { ikuti } & \end{array}$ & $\begin{array}{l}\text { Dialihkan ke } \\
\text { halaman } \\
\text { pengumuman } \\
\text { dari kelas yang } \\
\text { dipilih, terdapat } \\
\text { tabel data } \\
\text { pengumuman } \\
\text { yang } \\
\text { menampilkan } \\
\text { pengumuman } \\
\text { apa saja yang } \\
\text { ada dari kelas } \\
\text { yang dipilih }\end{array}$ & valid \\
\hline & $\begin{array}{l}\text { Notifik } \\
\text { asi } \\
\text { pengu } \\
\text { muman } \\
\text { pada } \\
\text { whatsa } \\
\text { pp }\end{array}$ & $\begin{array}{l}\text { Pengumuman } \\
\text { baru akan } \\
\text { diposting } \\
\text { pada jam } \\
19.30 \text { WIB. } \\
\text { Pastikan } \\
\text { nomor } \\
\text { whatsapp } \\
\text { yang anda } \\
\text { inputkan pada } \\
\text { profilku } \\
\text { benar. Periksa } \\
\text { notifikasi } \\
\text { whatsapp } \\
\text { anda pada } \\
\text { jam tersebut. }\end{array}$ & $\begin{array}{l}\text { Muncul } \\
\text { notifikasi dan } \\
\text { chat baru pada } \\
\text { whatsapp yang } \\
\text { berisi ada } \\
\text { pengumuman } \\
\text { baru yang di } \\
\text { unggah serta } \\
\text { deskripsi dari } \\
\text { pengumuman } \\
\text { tersebut. }\end{array}$ & valid \\
\hline Materi & $\begin{array}{l}\text { Tampil } \\
\text { kan } \\
\text { Materi }\end{array}$ & $\begin{array}{lr}\text { Pilih menu } \\
\text { materi pada } \\
\text { kelas yang } \\
\text { anda ikuti }\end{array}$ & $\begin{array}{l}\text { Dialihkan ke } \\
\text { halaman materi } \\
\text { dari kelas yang } \\
\text { dipilih, terdapat }\end{array}$ & valid \\
\hline
\end{tabular}




\begin{tabular}{|c|c|c|c|c|c|c|c|c|c|}
\hline $\begin{array}{c}\text { Kelas } \\
\text { Uji }\end{array}$ & $\begin{array}{c}\text { Butir } \\
\text { Uji }\end{array}$ & $\begin{array}{c}\text { Skenario } \\
\text { Pengujian }\end{array}$ & Hasil Pengujian & $\begin{array}{l}\text { Kesim } \\
\text { pulan }\end{array}$ & $\begin{array}{c}\text { Kelas } \\
\text { Uji }\end{array}$ & $\begin{array}{c}\text { Butir } \\
\text { Uji }\end{array}$ & $\begin{array}{c}\text { Skenario } \\
\text { Pengujian }\end{array}$ & Hasil Pengujian & $\begin{array}{l}\text { Kesim } \\
\text { pulan }\end{array}$ \\
\hline & & & $\begin{array}{lr}\text { tabel materi } \\
\text { dimana berisi } \\
\text { materi yang } \\
\text { telah di bagikan } \\
\text { oleh kelas yang } \\
\begin{array}{l}\text { dipilih dan } \\
\text { dapat di unduh }\end{array}\end{array}$ & & & $\begin{array}{l}\text { Notifik } \\
\text { asi } \\
\text { ujian } \\
\text { pada } \\
\text { whatsa } \\
\text { pp }\end{array}$ & $\begin{array}{l}\text { Ujian baru } \\
\text { akan } \\
\text { diposting } \\
\text { pada jam } \\
19.30 \text { WIB. } \\
\begin{array}{l}\text { Pastikan } \\
\text { nomor }\end{array}\end{array}$ & \multirow{3}{*}{$\begin{array}{l}\text { Muncul } \\
\text { notifikasi dan } \\
\text { chat baru pada } \\
\text { whatsapp yang } \\
\text { berisi ada ujian } \\
\text { baru yang di } \\
\text { unggah serta } \\
\text { deskripsi dari } \\
\text { ujian tersebut. }\end{array}$} & \multirow[t]{3}{*}{ valid } \\
\hline & $\begin{array}{l}\text { Downl } \\
\text { oad } \\
\text { Materi }\end{array}$ & $\begin{array}{l}\text { Unduh materi } \\
\text { yang ada pada } \\
\text { menu materi }\end{array}$ & $\begin{array}{l}\text { Muncul pop up } \\
\text { command untuk } \\
\text { mengunduh } \\
\text { file, file dapat } \\
\text { diunduh dan } \\
\text { dibuka dengan } \\
\text { normal. }\end{array}$ & valid & & & $\begin{array}{l}\text { whatsapp } \\
\text { yang anda } \\
\text { inputkan pada } \\
\text { profilku } \\
\text { benar. Periksa } \\
\text { notifikasi } \\
\text { whatsapp }\end{array}$ & & \\
\hline & \multirow{3}{*}{$\begin{array}{l}\text { Notifik } \\
\text { asi } \\
\text { materi } \\
\text { pada } \\
\text { whatsa } \\
\text { pp }\end{array}$} & \multirow{3}{*}{ 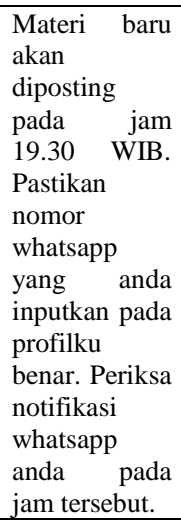 } & \multirow{3}{*}{$\begin{array}{lr}\text { Muncul } \\
\text { notifikasi dan } \\
\text { chat baru pada } \\
\text { whatsapp yang } \\
\text { berisi r ada } \\
\text { materi baru } \\
\text { yang di unggah } \\
\text { serta deskripsi } \\
\begin{array}{lr}\text { dari materi } \\
\text { tersebut. }\end{array}\end{array}$} & \multirow[t]{3}{*}{ valid } & & & $\begin{array}{l}\text { anda pada } \\
\text { jam tersebut. }\end{array}$ & & \\
\hline & & & & & Tugas & $\begin{array}{l}\text { Tampil } \\
\text { kan } \\
\text { Tugas }\end{array}$ & $\begin{array}{l}\text { Pilih menu } \\
\text { tugas pada } \\
\text { kelas yang } \\
\text { anda ikuti }\end{array}$ & $\begin{array}{l}\text { Dialihkan ke } \\
\text { halaman tugas } \\
\text { dari kelas yang } \\
\text { dipilih, terdapat } \\
\text { tabel data tugas } \\
\text { yang berisi } \\
\text { tugas yang } \\
\text { sedang } \\
\text { berlangsung } \\
\text { maupun tidak. }\end{array}$ & valid \\
\hline & & & & & & $\begin{array}{l}\text { Kerjak } \\
\text { an } \\
\text { Tugas }\end{array}$ & \begin{tabular}{l}
\multicolumn{2}{l}{ Kerjakan } \\
tugas yang \\
aktif pada \\
menu tugas
\end{tabular} & $\begin{array}{lr}\text { Dialihkan } & \text { ke } \\
\text { halaman } & \text { detail } \\
\text { tugas } & \text { yang } \\
\text { terdapat } & \text { tabel }\end{array}$ & valid \\
\hline \multirow[t]{3}{*}{ Ujian } & $\begin{array}{l}\text { Tampil } \\
\text { kan } \\
\text { Ujian }\end{array}$ & $\begin{array}{lr}\begin{array}{l}\text { Pilih } \\
\text { ujian }\end{array} \text { pada } \\
\text { kelas yang } \\
\text { anda ikuti }\end{array}$ & $\begin{array}{l}\text { Dialihkan ke } \\
\text { halaman ujian } \\
\text { dari kelas yang } \\
\text { dipilih, terdapat } \\
\text { tabel data ujian } \\
\text { yang berisi } \\
\text { ujian yang } \\
\text { sedang } \\
\text { berlangsung } \\
\text { maupun tidak. }\end{array}$ & valid & & & & $\begin{array}{l}\text { detail dari tugas } \\
\text { yang dipilih } \\
\text { dan form untuk } \\
\text { mengunggah } \\
\text { file beserta } \\
\text { dengan kotak } \\
\text { form deskripsi } \\
\text { dari file yang di } \\
\text { unggah. Saat } \\
\text { mengerjakan }\end{array}$ & \\
\hline & \multirow[t]{2}{*}{$\begin{array}{l}\text { Kerjak } \\
\text { an } \\
\text { Ujian }\end{array}$} & \multirow[t]{2}{*}{\begin{tabular}{l}
\multicolumn{2}{l}{ Kerjakan } \\
ujian yang \\
aktif pada \\
menu ujian
\end{tabular}} & \multirow{2}{*}{ 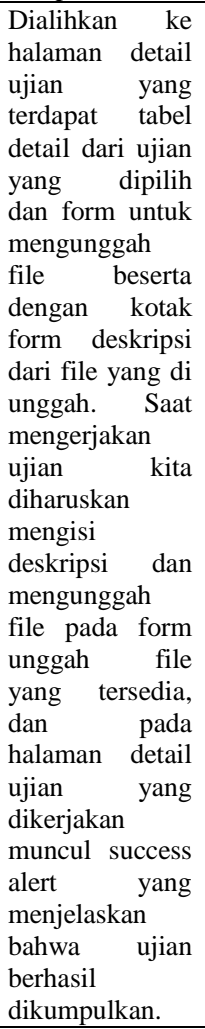 } & \multirow[t]{2}{*}{ valid } & & & & $\begin{array}{l}\text { tugas kita } \\
\text { diharuskan } \\
\text { mengisi } \\
\text { deskripsi dan } \\
\text { mengunggah } \\
\text { file pada form } \\
\text { unggah file } \\
\text { yang tersedia, } \\
\text { dan pada } \\
\text { halaman detail } \\
\text { tugas yang } \\
\text { dikerjakan } \\
\text { muncul success } \\
\text { alert yang } \\
\text { menjelaskan } \\
\text { bahwa tugas } \\
\text { berhasil } \\
\text { dikumpulkan. }\end{array}$ & \\
\hline & & & & & & $\begin{array}{l}\text { Notifik } \\
\text { asi } \\
\text { tugas } \\
\text { pada } \\
\text { whatsa } \\
\text { pp }\end{array}$ & 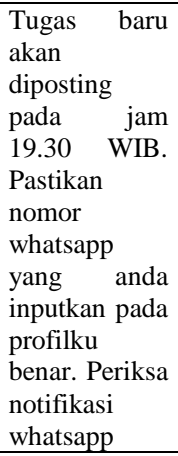 & $\begin{array}{l}\text { Muncul } \\
\text { notifikasi dan } \\
\text { chat baru pada } \\
\text { whatsapp yang } \\
\text { berisi ada tugas } \\
\text { baru yang di } \\
\text { unggah serta } \\
\text { deskripsi dari } \\
\text { tugas tersebut. }\end{array}$ & valid \\
\hline
\end{tabular}




\begin{tabular}{|c|c|c|c|c|}
\hline $\begin{array}{c}\text { Kelas } \\
\text { Uji }\end{array}$ & $\begin{array}{c}\text { Butir } \\
\text { Uji }\end{array}$ & $\begin{array}{c}\text { Skenario } \\
\text { Pengujian }\end{array}$ & Hasil Pengujian & $\begin{array}{l}\text { Kesim } \\
\text { pulan }\end{array}$ \\
\hline & & $\begin{array}{l}\text { anda pada } \\
\text { jam tersebut. }\end{array}$ & & \\
\hline \multirow[t]{3}{*}{ Diskusi } & $\begin{array}{l}\text { Diskusi } \\
\text { Umum }\end{array}$ & $\begin{array}{l}\text { Ikuti diskusi } \\
\text { umum yang } \\
\text { tersedia }\end{array}$ & $\begin{array}{l}\text { Dapat } \\
\text { mengakses } \\
\text { halaman diskusi } \\
\text { umum yang } \\
\text { tersedia, dan } \\
\text { dapat mengirim } \\
\text { komentar atas } \\
\text { diskusi umum } \\
\text { yang sedang } \\
\text { berlangsung }\end{array}$ & valid \\
\hline & $\begin{array}{l}\text { Diskusi } \\
\text { Video } \\
\text { Confer } \\
\text { ence }\end{array}$ & $\begin{array}{l}\text { Ikuti diskusi } \\
\text { video } \\
\text { conference } \\
\text { yang tersedia }\end{array}$ & $\begin{array}{l}\text { Dapat memulai } \\
\text { video } \\
\text { conference, } \\
\text { video } \\
\text { conference } \\
\text { berfungsi } \\
\text { normal seperti } \\
\text { kamera dan } \\
\text { audio bekerja } \\
\text { normal, dan } \\
\text { dapat } \\
\text { mengakhiri } \\
\text { video } \\
\text { conference }\end{array}$ & valid \\
\hline & $\begin{array}{l}\text { Notifik } \\
\text { asi } \\
\text { diskusi } \\
\text { pada } \\
\text { whatsa } \\
\text { pp }\end{array}$ & 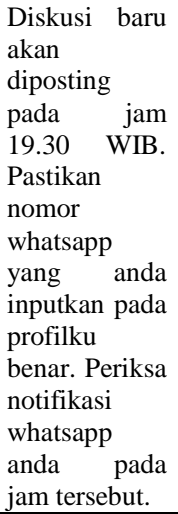 & $\begin{array}{lr}\text { Muncul } & \\
\text { notifikasi } & \text { dan } \\
\text { chat baru pada } \\
\text { whatsapp yang } \\
\text { berisi ada } \\
\text { diskusi baru } \\
\text { yang di buka. }\end{array}$ & valid \\
\hline \multirow[t]{2}{*}{$\begin{array}{c}\text { BOT } \\
\text { Whatsa } \\
\text { pp }\end{array}$} & $\begin{array}{l}\text { Cek } \\
\text { Tugas }\end{array}$ & $\begin{array}{lr}\text { Cek daftar } \\
\text { tugas anda } \\
\text { melalui } \quad \text { bot } \\
\text { whatsapp } \\
\text { learning }\end{array}$ & $\begin{array}{l}\text { Muncul daftar } \\
\text { tugas yang } \\
\text { belum } \\
\text { dikerjakan } \\
\text { sebanyak } 3 \\
\text { tugas, akan } \\
\text { tetapi } \\
\text { sebelumnya } \\
\text { saya telah } \\
\text { mengerjakan 1 } \\
\text { tugas, jadi tugas } \\
\text { yang belum di } \\
\text { kerjakan } \\
\text { seharusnya 2 } \\
\end{array}$ & valid \\
\hline & $\begin{array}{l}\text { Cek } \\
\text { Ujian }\end{array}$ & $\begin{array}{l}\text { Cek daftar } \\
\text { ujian anda } \\
\text { melalui } \quad \text { bot } \\
\text { whatsapp e- } \\
\text { learning }\end{array}$ & 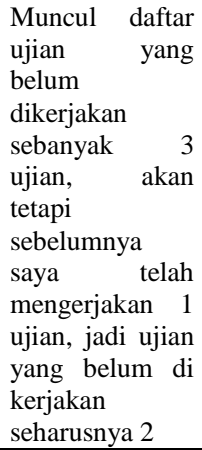 & valid \\
\hline
\end{tabular}

Skenario pengujian keamanan dilakukan dengan pengujian pada sisi kriptografi dan standar pengujian keamanan web lainnya, yaitu pengujian SQL Injection, dan pengujian site-to-scripting. Pada pengujian site-toscripting menunjukkan keamanan sistem informasi tidak berhasil ditembus. Script yang diinputkan dibaca sebagai proses abnormal, dan proses berhasil dihentikan oleh sistem. Pengujian SQL Injection dengan menyelipkan syntax sql pada salah satu form input sistem informasi menunjukkan hasil yang baik. Syntax yang diinputkan hanya dibaca sebagai teks biasa. Pengujian SQL Injection juga dilakukan dengan tools untuk melakukan pengujian. Pengujian dilakukan dengan mencoba menambahkan syntax sql melalui url sistem informasi. Hasil dari pengujian tersebut menunjukkan tidak ada syntax sql yang berhasil dijalankan.

\section{KESIMPULAN}

Dalam rangka mempermudah interaksi dan evaluasi proses pembelajaran dengan metode daring, dilakukan integrasi video conferece dalam aplikasi pembelajaran siswa Sekolah Dasar untuk kemudahan interaksi dan evaluasi proses belajar mengajar secara daring, sehingga dukungan pembelajaran dengan metode daring dapat berdampak maksimal pada perkembangan Pendidikan.

Dari hasil kegiatan integrasi video conferece dalam aplikasi pembelajaran siswa Sekolah Dasar yang dilakukan telah memberikan manfaat yang baik dalam membantu proses belajar mengajar. Dengan adanya sistem tersebut proses pembelajaran jarak jauh menjadi lebih mudah, lebih interaktif, aktif, efektif, serta efisien. Hal ini menunjukkan bahwa tujuan dari kegiatan penelitian telah terpenuhi.

Dari data - data hasil pengujian dengan whitebox dan blackbox didapati sistem yang dibangun dengan metode SDLC berfungsi dengan baik, sesuai harapan, dan telah berhasil melewati serangkaian skenario pengujian dari sisi blackbox maupun whitebox.

\section{DAFTAR PUSTAKA}

[1] W. Setiawan, "Era Digital dan Tantangannya," Semin. Nas. Pendidik., pp. 1-9, 2017.

$$
\text { M. Husaini, "PEMANFAATAN }
$$
TEKNOLOGI INFORMASI DALAM BIDANG PENDIDIKAN (E-Education)," $J$. Mikrotik, vol. 2, no. 1, 2014.

[3] D. Kartikawati and Nurhasanah, "Cerita Sebagai Medium Membangun Nilai-Nilai Karakter Di Sekolah Taman Kanak-Kanak Annizomiyah Pejaten Jakarta Selatan," Din. J. Pengabdi. Kpd. Masy., vol. 3, no. 2, pp. 340349, 2019.

[4] A. Nata, "Pendidikan Islam Di Era Milenial," Conciencia, vol. 18, no. 1, pp. 10-28, 2018. 
[5] S. Saleh, "Peran Lembaga Pendidikan Dalam Membentuk Karakter Bangsa," Semin. Nasioonal Pendidik. Ilmu-Ilmu Sos. Membentuk Karakter Bangsa Dalam Rangka Daya Saing Glob., pp. 101-112, 2016.

[6] A. Akbar and N. Noviani, "Tantangan dan Solusi Dalam Perkembangan Teknologi Pendidikan di Indonesia," Pros. Semin. Nas. Pendidik. Progr. Pascasarj. Univ. PGRI Palembang, pp. 18-25, 2019.

[7] A. Sadikin and A. Hamidah, "Pembelajaran Daring di Tengah Wabah Covid-19 ( Online Learning in the Middle of the Covid-19 Pandemic )," BIODIK J. Ilm. Pendidik. Biol., vol. 6, no. 1, pp. 214-224, 2020.

[8] A. Hermanto, A. K. Darmawan, and E. S. Y. Wrahatnala, "Perbaikan Manajemen Proses Perangkat Lunak Berbasis Web Menggunakan Pemodelan WSPIM," KONVERGENSI, vol. 15 , no. 2, pp. 1-9, 2019.

[9] Supangat, F. H. Chandar, and A. Hermanto, "The design of e-learning applications by considering aspects of the u ser' s personality based on students take courses in humancomputer interaction," MATEC Web Conf., vol. 03009, no. 154, 2018.

[10] A. Hermanto, Supangat, and F. Mandita, "Evaluasi Usabilitas Layanan Sistem Informasi Akademik Berdasarkan Kombinasi ServQual dan Webqual,” J. Inf. Syst. Eng. Bus. Intell., vol. 3, no. 1, pp. 33-39, 2017. 